\title{
Loxosceles gaucho Spider Venom: An Untapped Source of Antimicrobial Agents
}

\author{
Paula J Segura-Ramírez ${ }^{1,2}$ and Pedro I Silva Júnior ${ }^{1, *}$ \\ 1 Special Laboratory for Applied Toxinology (LETA), Butantan Institute, São Paulo CEP 05503-900, SP, Brazil; \\ paula.segura@icb.usp.br \\ 2 Institute of Biomedical Sciences, University of São Paulo, São Paulo CEP 05508-900, SP, Brazil \\ * Correspondence: pedro.junior@butantan.gov.br; Tel.: +55-11-2627-9731
}

Received: 26 September 2018; Accepted: 29 November 2018; Published: 6 December 2018

\begin{abstract}
The remarkable ability of microorganisms to develop resistance to conventional antibiotics is one of the biggest challenges that the pharmaceutical industry currently faces. Recent studies suggest that antimicrobial peptides discovered in spider venoms may be useful resources for the design of structurally new anti-infective agents effective against drug-resistant microorganisms. In this work, we found an anionic antibacterial peptide named $\mathrm{U}_{1}-\mathrm{SCRTX}$-Lg1a in the venom of the spider Loxosceles gaucho. The peptide was purified using high-performance liquid chromatography (HPLC), its antimicrobial activity was tested through liquid growth inhibition assays, and its chemical properties were characterized using mass spectrometry. $\mathrm{U}_{1}$-SCRTX-Lg1a was found to show a monoisotopic mass of $1695.75 \mathrm{Da}$, activity against Gram-negative bacteria, a lack of hemolytic effects against human red blood cells, and a lack of cytotoxicity against human cervical carcinoma cells (HeLa). Besides this, the sequence of the peptide exhibited great similarity to specific regions of phospholipases D from different species of Loxosceles spiders, leading to the hypothesis that $\mathrm{U}_{1}$-SCRTX-Lg1a may have originated from a limited proteolytic cleavage. Our data suggest that $\mathrm{U}_{1}$-SCRTX-Lg1a is a promising candidate for the development of new antibiotics that could help fight bacterial infections and represents an exciting discovery for Loxosceles spiders.
\end{abstract}

Keywords: Loxosceles; venom; anionic antimicrobial peptides; antimicrobial resistance

Key Contribution: Loxosceles gaucho venom has an anionic antimicrobial peptide effective against Gram-negative bacteria.

\section{Introduction}

Despite the great advances made on the field of antibiotic therapy since the early 20th century, infectious diseases remain major causes of death in human population due to the great ability of microorganisms to develop resistance to conventional antibiotics, compromising their effectiveness. Because of this, it has become urgent to find novel sources of non-traditional antibiotics in order to develop new drugs effective against pathogenic microorganisms [1].

In this regard, antimicrobial peptides (AMPs) emerge as promising candidates for the control of infectious diseases due to their low resistance rates, potent activity, and unique mechanism of action [2,3]. These endogenous molecules, which are mostly genetically encoded, constitute a primitive immune defense mechanism present in the vast majority of living organisms: viruses, bacteria, plants, insects, fishes, amphibians, and mammals [4]. This group of peptides exhibits a broad range of biological properties, from the direct neutralization of cancer cells and invading pathogens such as bacteria, fungi, viruses, and protozoan parasites, to the modulation of the immune response of the host [5-7]. 
The venom of spiders contains pore-forming peptides whose main purpose is to depolarize cell membranes and damage the tissues of their prey [1]. However, some remarkable examples have shown that these peptides also may play a role as genuine antimicrobials by protecting the spider against the potential invasion of infectious organisms arising from the injection of venom into their prey [8-10]. Consequently, in recent years, the idea of using AMPs discovered in spider venoms as tools for the design of structurally novel drugs has received much attention from experts in the field of biotechnology and the pharmaceutical industry [11], leading to the identification and study of several of these molecules [12-18]. Among these peptides, Juruin shows a lack of hemolytic activity against human blood cells [13], while LyeTx I and Lycosin-II display a weak hemolytic activity in high concentrations [16,18]. In the case of CIT 1a, a negligible effect on cell viability was observed [14].

Brown spiders (the Loxosceles genus) are members of the select group of the world's most venomous spiders. Their bite causes a condition called loxoscelism and has two clinical manifestations: cutaneous and systemic, which take place approximately in 83.3 and $16.7 \%$ of cases, respectively [19]. The first and most frequent manifestation is associated with necrotic skin lesions, which advance gradually from the bite. On the other hand, at the systemic level, it is common to observe weakness, fever, nausea and vomiting, hematuria, pruritic reactions, renal failure, jaundice hemoglobinuria, and disseminated intravascular coagulation [20,21]. Due to the prevalence of loxoscelism as a public health problem in several South American countries such as Argentina, Peru, Chile, and Brazil, brown spider venoms have been studied in order to increase the knowledge about the pathophysiology of loxoscelism [22]. Although the complete content of the venom is not yet fully understood, many investigations have shown that it consists of a complex mixture of proteins and peptides with a molecular mass profile in the range of 2 to $40 \mathrm{kDa}$. These components have toxic and/or enzymatic activities and act synergistically [20-24]. To date, many brown spider toxins have been described and their corresponding biochemical properties have been characterized, providing key information about their great potential for biotechnological purposes such as the design of pharmacological tools, diagnostic and immunotherapeutic reagents, cytotoxicity inducers, and biopesticides [20,21,25]. Included among these molecules are phospholipases D [26-35], astacins (metalloproteases) [36-41], hyaluronidases [42-46], serine proteases [44,47-50], translationally controlled tumor protein (TCTP) [47,48,51], and inhibitor cystine knot (ICK) peptides [24,52,53].

Being aware of the antibiotic resistance problem, through the present work we aim to generate data that may lead to the creation of new potential drugs effective against pathogenic microorganisms. Furthermore, this work has the additional objectives of increasing the literature about AMPs from Loxosceles spiders and setting up a basis for future studies directed to elucidate new modes of action of these molecules. Herein, we present the characterization of a novel AMP isolated from Loxosceles gaucho venom.

\section{Results and Discussion}

\subsection{Purification of $U_{1}-S C R T X-L g 1$ from the Venom of L. gaucho}

The crude venom of L. gaucho was collected by electrostimulation. The first stage of venom separation was performed by reversed-phase high-performance liquid chromatography (RP-HPLC), which resulted in isolation of at least 32 different fractions that were analyzed in liquid growth inhibitory assays using Escherichia coli SBS363, Micrococcus luteus A270, Aspergillus niger, and Candida albicans MDM8. The antimicrobial activity occurred in the fraction 18 eluted with retention times of 49.1-50.6 min (Figure 1), which was effective only against E. coli SBS363, a Gram-negative bacterium. This fraction was further applied to the same C18 RP-HPLC column for the purification of individual compounds. Among these, only one had a pronounced antibacterial activity: $\mathrm{U}_{1}$-SCRTX-Lg1a (Figure 1). This name was established according to the nomenclature indicated by King et al. [54]. The fraction was quantified based on absorbance at $205 \mathrm{~nm}$ and its final concentration in $500 \mu \mathrm{L}$ of ultrapure water was $23 \mu \mathrm{M}(38 \mu \mathrm{g} / \mathrm{mL})$. 


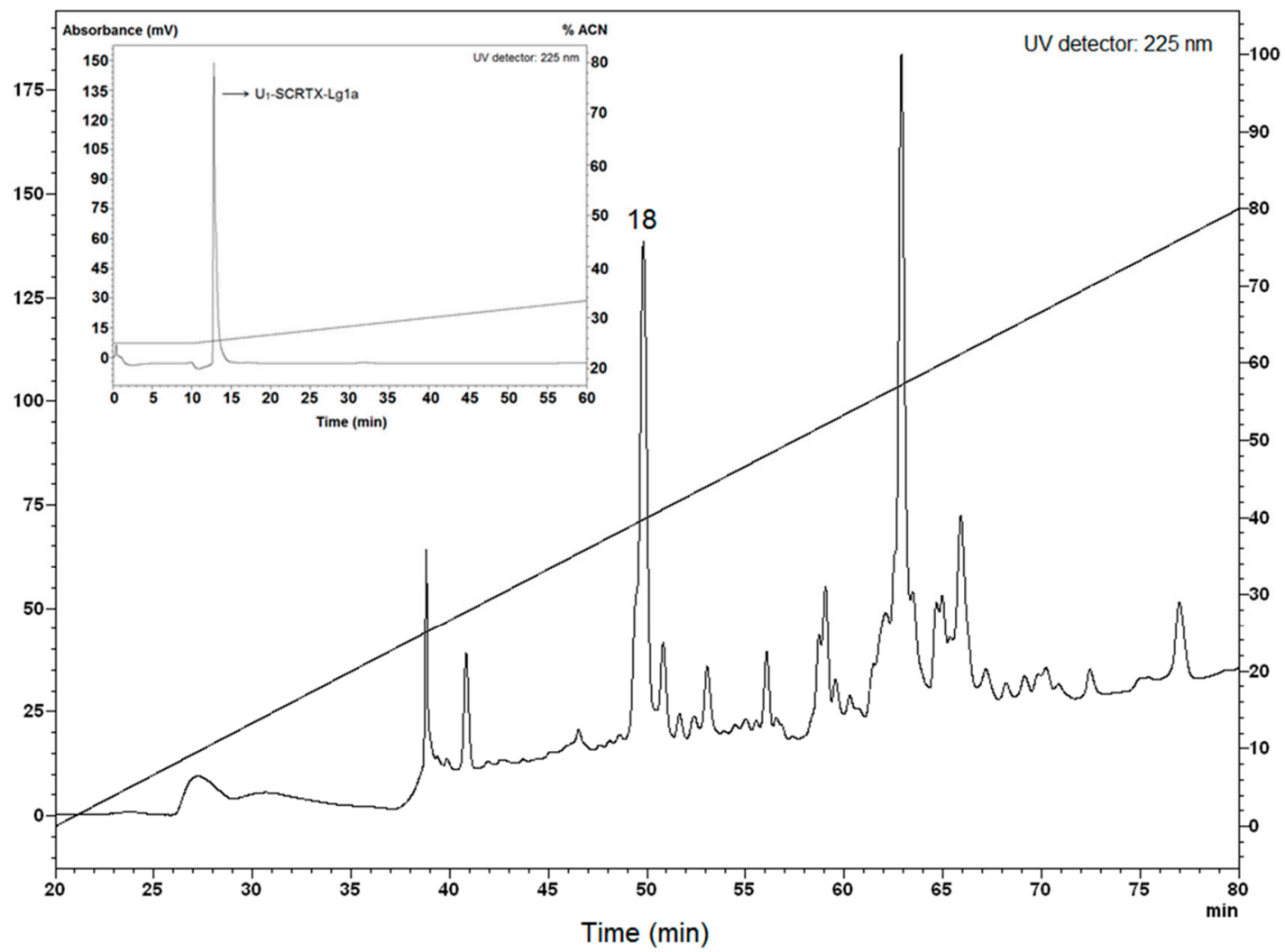

Figure 1. Purification of $U_{1}$-SCRTX-Lg1a from the crude venom of L. gaucho by RP-HPLC. The acidified venom sample was analyzed on a semi-preparative column Jupiter C18 with a linear gradient from $0 \%$ to $80 \% \mathrm{ACN}$ in acidified water at a flow rate of $1.5 \mathrm{~mL} / \mathrm{min}$ over $60 \mathrm{~min}$. The numbered peak (18) corresponds to the fraction that showed antimicrobial activity and was eluted at 49.1-50.6 min. Fraction 18 was re-chromatographed on the same system and run from $26 \%$ to $46 \%$ ACN in acidified water over $60 \mathrm{~min}$. The peak indicated with an arrow corresponds to the $\mathrm{U}_{1}$-SCRTX-Lg1a fraction.

This finding represents an exciting new source of information for the production of antimicrobial drugs and contributes to the limited existing literature on antimicrobial molecules from the venom of Loxosceles spiders. This fact is quite surprising because the venom of these organisms has been well-studied due to its medical importance and several of the toxins that compose it have been characterized, providing new information about the pathophysiology of envenomation and the biotechnological potential of these molecules [20,21]. However, so far there is only one report that indicates that $L$. gaucho venom contains low-molecular-mass molecules with antimicrobial activity against Pseudomonas aeruginosa. The study also mentions that the whole venom of this spider does not influence the proliferation of $P$. aeruginosa, but increases its biofilm formation, as well as the production of gelatinase and caseinase [55].

\subsection{Antimicrobial Activity and Minimum Inhibitory Concentrations (MICs)}

$\mathrm{U}_{1}$-SCRTX-Lg1a was assessed for antimicrobial activity against five species of Gram-negative bacteria, three species of Gram-positive bacteria, one species of fungus, and two species of yeast (Table 1). All Gram-negative bacteria species tested showed sensitivity to $\mathrm{U}_{1}$-SCRTX-Lg1a, which was active at a concentration range between $1.15 \mu \mathrm{M}(1.9 \mu \mathrm{g} / \mathrm{mL})$ and $4.6 \mu \mathrm{M}(7.6 \mu \mathrm{g} / \mathrm{mL})$. P. aeruginosa ATCC 27853 was the most sensitive to the fraction, with an MIC of $1.15 \mu \mathrm{M}(1.9 \mu \mathrm{g} / \mathrm{mL})$. $\mathrm{U}_{1}$-SCRTX-Lg1a was not effective against Gram-positive bacteria, fungus, or yeast at the concentrations investigated (Table 1). 
Table 1. Antimicrobial activity spectrum of U1-SCRTX-Lg1a.

\begin{tabular}{lc}
\hline \multicolumn{1}{c}{ Microorganism } & MIC $(\mu \mathbf{M}(\mu \mathrm{g} / \mathbf{m L}))^{\mathbf{1}}$ \\
\hline Gram-negative bacteria & \\
Escherichia coli SBS363 & $4.6(7.6)$ \\
E. coli D31 & $4.6(7.6)$ \\
Pseudomonas aeruginosa ATCC 27853 & $1.15(1.9)$ \\
P. aeruginosa PA14 & $4.6(7.6)$ \\
Enterobacter cloacae $\beta-12$ & $2.3(3.8)$ \\
Gram-positive bacteria & \\
Micrococcus luteus A270 & ND \\
Staphylococcus aureus ATCC 29213 & ND \\
Bacillus subtilis ATCC 6633 & ND \\
Fungus & \\
Aspergillus niger & ND \\
Yeasts & \\
Candida albicans MDM8 & ND \\
Candida krusei IOC 4559 & ND
\end{tabular}

MIC, minimum inhibitory concentration; ND, not detectable (antimicrobial activity not detected in the concentrations assayed). ${ }^{1}$ The MIC refers to the minimal peptide concentration without visible cell growth in liquid medium.

Interestingly, $\mathrm{U}_{1}$-SCRTX-Lg1a has lower MICs against the Gram-negative bacterial strains tested than those of Lacrain, an AMP found in the body extract of centipede Scolopendra viridicornis previously identified by our group [56]. On the other hand, compared to Gomesin, a potent host defense

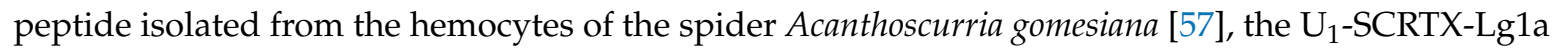
MICs against E. coli SBS363 and E. coli D31 are higher; however, it has a slightly more pronounced antimicrobial effect against $P$. aeruginosa ATCC 27853 and Enterobacter cloacae $\beta-12$. It is worth noting that $P$. aeruginosa PA14, a hyper-virulent burn wound isolated strain, was also sensitive to U1-SCRTX-Lg1a.

Because of the antibacterial activity described, we believe that $U_{1}-S C R T X-L g 1 a$ could have Gram-negative specificity. Under this assumption, it can be said that this fraction has a great therapeutic potential, considering that recently identified AMPs that were introduced into clinical practice mainly display activity against Gram-positive bacteria while being ineffective against Gram-negative organisms due to their use of multiple mechanisms that work synergistically to resist AMPs [58].

Nonetheless, it would be impelling to investigate other biological activities of this fraction in order to have a clearer notion of all its biotechnological potential, since other molecules with several properties are constantly reported in the literature. For example, spinigerin, a 25-amino acid peptide obtained from the fungus-growing termite Pseudacanthotermes spiniger, exhibits antibacterial, antifungal, and antiviral properties, and recently it was also found that spinigerin induces apoptosis-like cell death in Leishmania donovani [59].

\subsection{Hemolytic Activity}

To determine the effect of $\mathrm{U}_{1}$-SCRTX-Lg1a on human erythrocytes at the antimicrobial concentrations, its hemolytic activity was tested. After incubating red blood cells from a healthy donor with the fraction up to a concentration of $137 \mu \mathrm{M}$ for $3 \mathrm{~h}$ at $37^{\circ} \mathrm{C}$, no hemoglobin release was observed, indicating that $\mathrm{U}_{1}$-SCRTX-Lg1a does not cause lysis of human erythrocytes within these concentrations (Figure 2). These data suggest that the mechanism of action of $\mathrm{U}_{1}$-SCRTX-Lg1a does not involve the disruption of cell membranes and that this fraction is not part of the group of toxins responsible for the hemolytic properties ascribed to the whole venom of Loxosceles spiders [21]. 


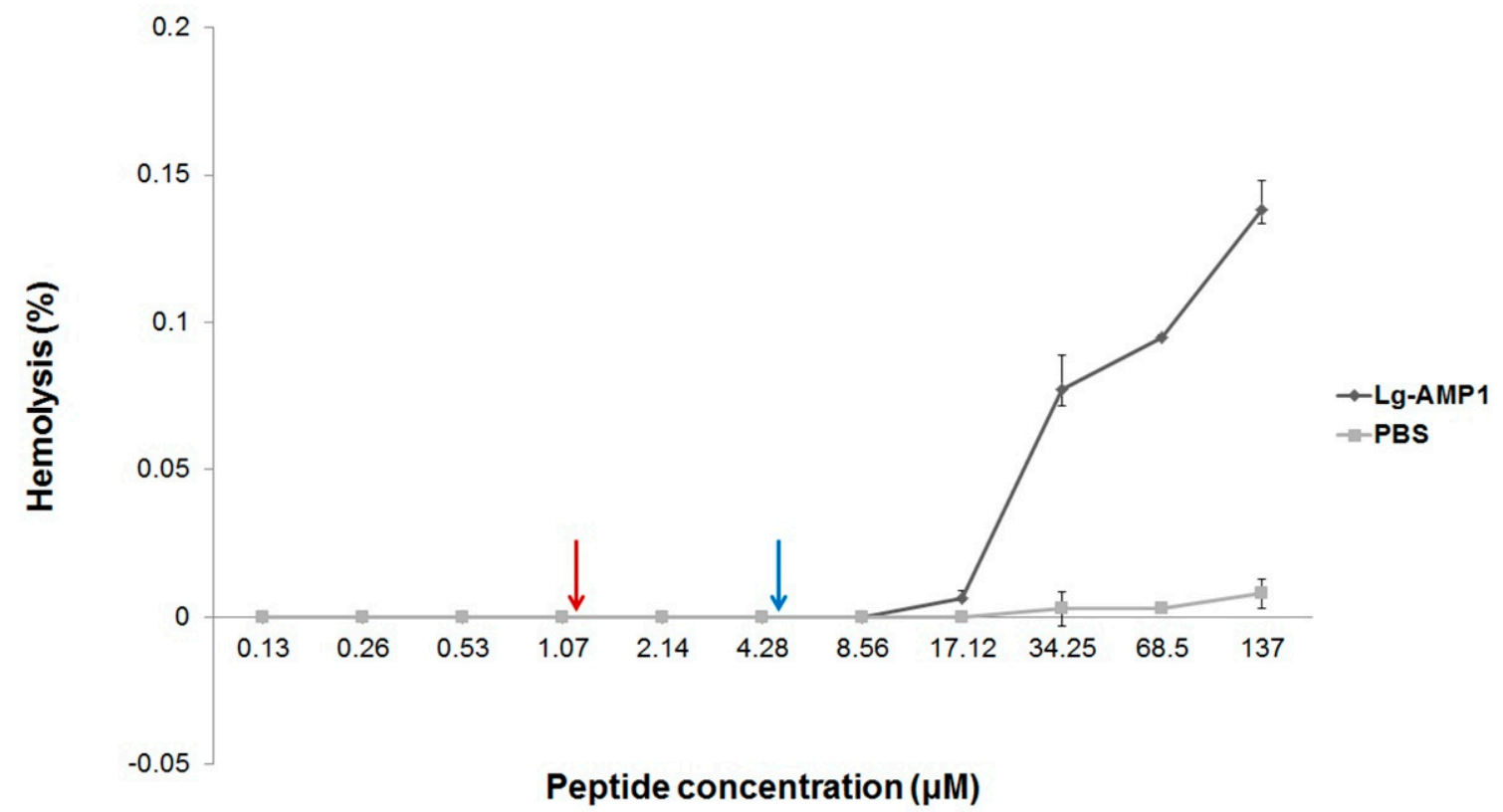

Figure 2. Hemolytic effects of U1-SCRTX-Lg1a on human erythrocytes. The concentration-response curve of hemolytic activity of the peptide shows its extremely low toxicity even at the maximum concentration tested $(137 \mu \mathrm{M})$, which is very similar to the negative control (phosphate-buffered saline (PBS)). The two arrows (red and blue) indicate the concentration range in which the fraction showed antimicrobial activity. The results represent the mean \pm standard deviation of three independently developed experiments.

For antimicrobial molecules to be interesting for systemic applications, they must show low toxicity against erythrocytes [60]. Taking this into account, $\mathrm{U}_{1}-\mathrm{SCRTX}-\mathrm{Lg} 1 \mathrm{a}$ emerges as a promising template for the development of novel antibiotics.

\subsection{Cytotoxicity of $U_{1}-S C R T X-L g 1 a$}

The cytotoxicity of $\mathrm{U}_{1}$-SCRTX-Lg1a against human cervical carcinoma cells (HeLa) was assessed using the 3-(4,5-dimethylthiazol-2-yl)-2,5-diphenyltetrazolium bromide (MTT) assay. After incubating the cells with the fraction at various concentrations $(0.88 \mu \mathrm{M}$ to $112.74 \mu \mathrm{M})$, it was observed that the amount of formazan produced by the mitochondria of living cells did not vary considerably, which indicates that U1-SCRTX-Lg1a did not affect HeLa cell viability even at a high concentration of $112.74 \mu \mathrm{M}$ (Figure 3). This lack of cytotoxicity presented by the fraction against HeLa cells at the antimicrobial concentration range suggests a possible specificity of U1-SCRTX-Lg1a against bacteria, leading us to consider this as an indicator of its safety for the development of antibiotics for mammalian organisms. 


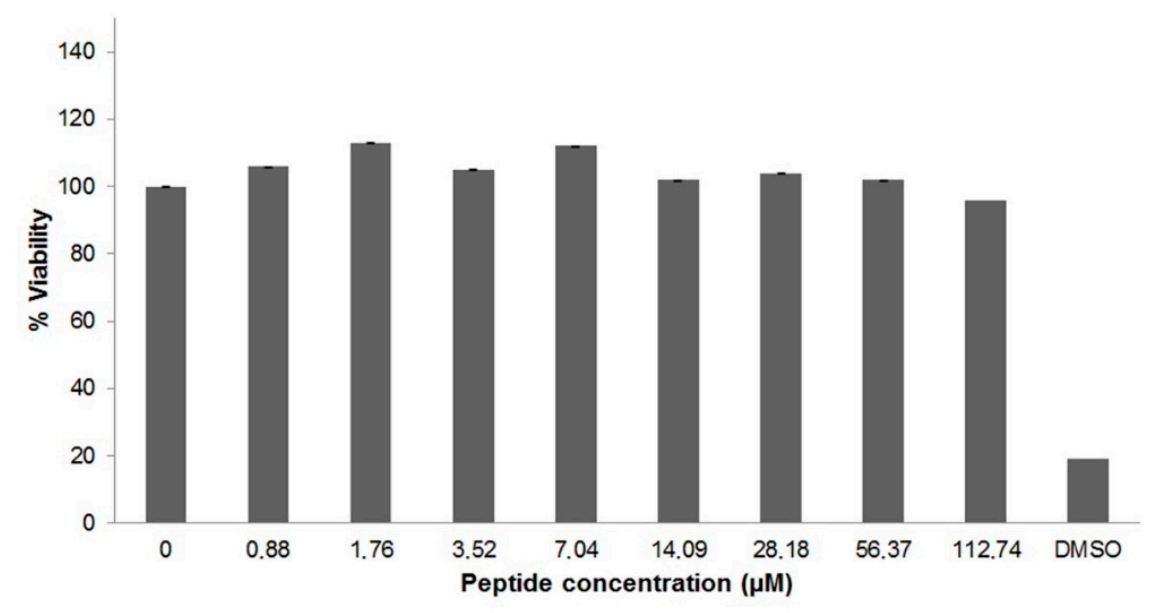

Figure 3. Cytotoxicity of U1-SCRTX-Lg1a. HeLa cells were incubated with various concentrations $(0.88 \mu \mathrm{M}$ to $112.74 \mu \mathrm{M})$ of the fraction for $48 \mathrm{~h}$ at $37^{\circ} \mathrm{C}$. Effects on cell viability were determined by performing an MTT assay. Untreated HeLa cells were used as a negative control and HeLa cells treated with DMSO served as a positive control. The results correspond to the mean \pm standard deviation of three experiments carried out independently.

\section{5. $U_{1}$-SCRTX-Lg1a Identification}

The silver-stained 12\% SDS-polyacrylamide gel electrophoresis (SDS-PAGE) analysis did not show bands corresponding to the purified antimicrobial $\mathrm{U}_{1}$-SCRTX-Lg1a within the molecular weight range established by the marker (MW); instead, it was observed that the fraction accumulated near the bottom of the gel, while other protein components of L. gaucho crude venom (CV) whose molecular weights are higher than $10 \mathrm{kDa}$ did appear on the gel and were clearly separated (Figure 4). Through this, we inferred that $\mathrm{U}_{1}$-SCRTX-Lg1a has a molecular weight lower than $10 \mathrm{kDa}$.

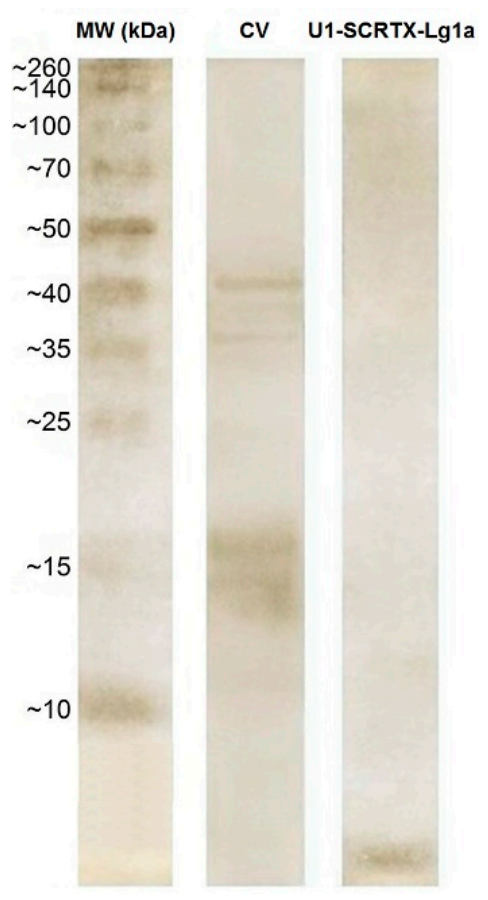

Figure 4. Electrophoretic analysis of $\mathrm{U}_{1}$-SCRTX-Lg1a. Silver-stained 12\% SDS-PAGE gel of the crude venom of L. gaucho (CV) $(5 \mu \mathrm{g})$ and purified antimicrobial $\mathrm{U}_{1}$-SCRTX-Lg1a $(2.5 \mu \mathrm{g})$ under non-reducing conditions. On the left are numbers that correspond to the positions of molecular weight markers (MW) expressed in $\mathrm{kDa}$. 
Accurate molecular mass and sequence of $\mathrm{U}_{1}$-SCRTX-Lg1a were established by tandem mass spectrometry (MS/MS) data interpretation using PEAKS Studio software (v8). The fragmentation pattern revealed a peptide sequence of 16 amino acids (VGTDFSGNDDISDVQK) with a monoisotopic mass of $1695.75 \mathrm{Da}$ and an average local confidence (ALC) of $88 \%$ (Figure 5). The $\mathrm{U}_{1}$-SCRTX-Lg1a database searches performed through the PEAKS DB tool revealed that this native peptide fraction of L. gaucho venom may be derived from the phospholipase D LgRec1 [33], covering 6\% of the whole protein sequence (Figure 6).

To our knowledge, $\mathrm{U}_{1}$-SCRTX-Lg1a is the first antimicrobial peptide isolated from the venom of L. gaucho, an araneomorph spider that belongs to the Sicariidae family. Before this study, the only peptides reported for Loxosceles spiders were ICKs [24,52,53], a family of structural peptides with several cysteine residues that form disulfide bonds that result in a knot, which have generated great interest due to their ability to specifically bind to insect ion channels, conferring them great potential for the development of efficient bioinsecticides for the control of pests that can affect the agricultural sector or insects vectors of infectious diseases [20,21]. Considering this, it is safe to say that $U_{1}-S C R T X-L g 1 a$ is the newest member of the group of bioactive peptides isolated from the venom of Loxosceles spiders. As such this complex protein mixture invites a new biotechnological approach in view that it may represent a valuable alternative to standard antimicrobial therapies as a new and non-conventional anti-infective agent. 


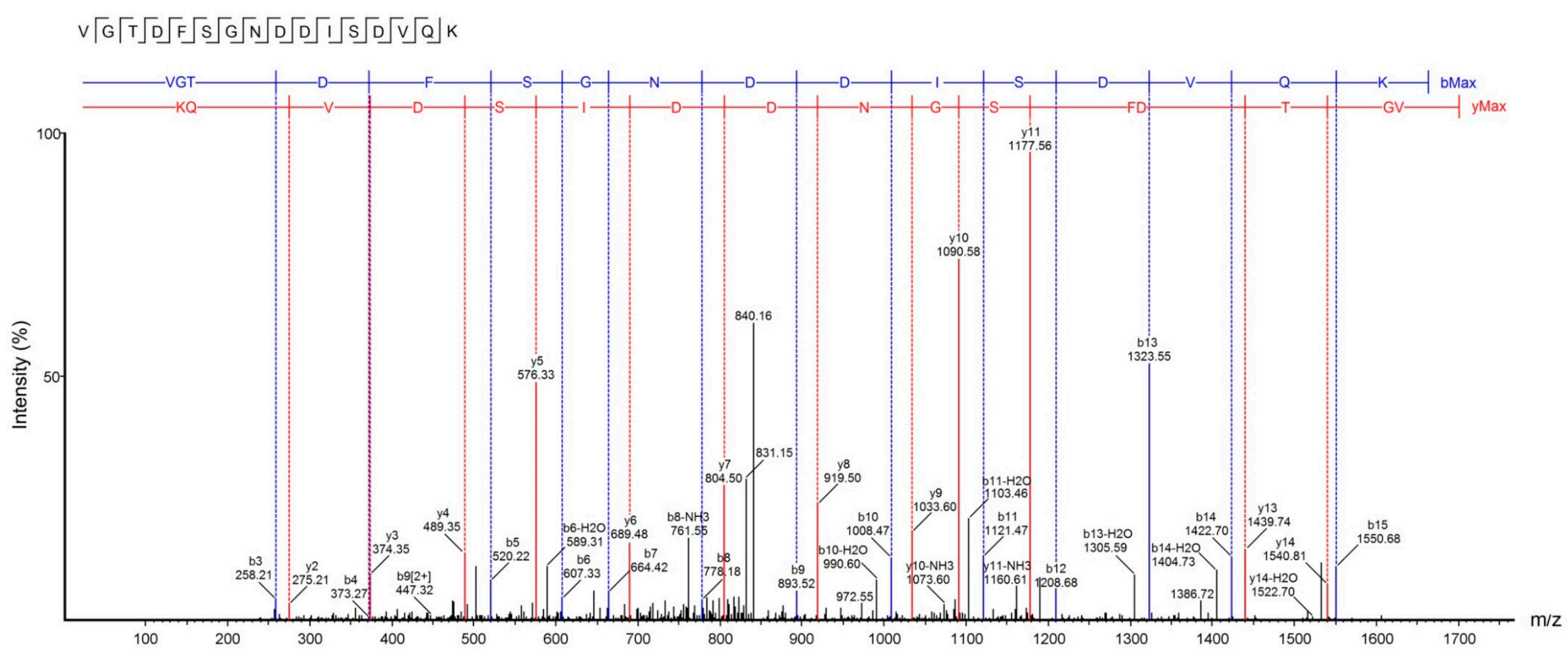

Figure 5. Collision-induced dissociation (CID) spectrum of the de novo sequenced antimicrobial peptide, U1-SCRTX-Lg1a. The ions belonging to -y (red) and -b (blue) series indicated in the spectrum correspond to the amino acid sequence of the peptide: VGTDFSGNDDISDVQK. The fragments of the sequenced peptide are represented by standard amino acid code letters. 


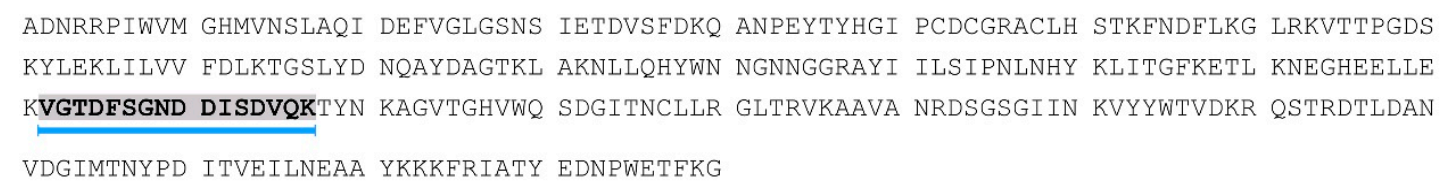

Figure 6. Peptide spectrum match indicated by a blue line below the sequence of the phospholipase D

LgRec1. $\mathrm{U}_{1}$-SCRTX-Lg1a covered $6 \%$ of the whole protein sequence.

\subsection{Structure and Physicochemical Characteristics of $U_{1}-S C R T X-L g 1 a$}

Sequence similarity searches with the Basic Local Alignment Search Tool (BLAST) allowed us to perform a multiple alignment analysis of the amino acid sequence of $U_{1}$-SCRTX-Lg1a using the Clustal Omega program. BLAST searches and sequence alignment exhibited the peptide homology to specific regions of nine phospholipases D found in the venom of Loxosceles spiders (Figure 7). The amino acid sequences of phospholipases D LgRec1 (fragments 162-177) and Loxtox_s1D (fragments 188-203) had the highest homology to $U_{1}$-SCRTX-Lg1a, showing a $100 \%$ identity match with the peptide. On the other hand, LvSicTox-alphaIC1bv (fragments 154-169), LvSicTox-alphaIC1aii (fragments 155-170), LgSicTox-alphaIA1 (fragments 162-177), LsaSicTox-alphaIB1avi (fragments 155-170), LsaSicTox-alphaIB1av (fragments 152-167), and LruSicTox-alphaIC1a (fragment 155-170) had a lower but still significant homology to the peptide with an identity match range between $88-81 \%$. Finally, LiSicTox-alphaII2 had the lowest homology to $\mathrm{U}_{1}$-SCRTX-Lg1a, exhibiting a 75\% identity match. The alignment also showed that all analyzed sequences contain two regions with identical amino acids: one of two residues (VG) and another one of eight residues (DFSGNDDI). Furthermore, three positions are strongly conserved and two are occupied by residues of functional similarity ( $D$ and $\mathrm{E}$, both with negatively charged $\mathrm{R}$ groups; $\mathrm{V}$ and I, both with nonpolar R groups), indicating that these positions represent conservative amino acid exchanges [61].

\begin{tabular}{ll}
\multicolumn{1}{c}{ Origin } & \multicolumn{1}{c}{ Name } \\
Loxosceles gaucho & Lg-AMP1 \\
Loxosceles gaucho & LgRec1 \\
Loxosceles similis & Loxtox_s1D \\
Loxosceles variegata & LvSicTox-alphaIC1bv \\
Loxosceles variegata & LvSicTox-alphaIC1aii \\
Loxosceles gaucho & LgSicTox-alphaIA1 \\
Loxosceles sabina & LsaSicTox-alphaIB1avi \\
Loxosceles sabina & LsaSicTox-alphaIB1av \\
Loxosceles rufescens & LruSicTox-alphaIC1a \\
Loxosceles intermedia & LiSicTox-alphaII2
\end{tabular}

$\begin{array}{rclr} & \text { Sequence } & & \text { \&Identity } \\ 1 & \text { VGTDFSGNDDISDVQK } & 16 & \\ 160 & \text { EKVGTDFSGNDDISDVQKTY } & 179 & 100 \\ 186 & \text { KKVGTDFSGNDISDVQRTY } & 205 & 100 \\ 152 & \text { DKVGYDFSGNDDIGDVQKIY } & 171 & 88 \\ 153 & \text { EKVGHDFSGNDDISEVQRAY } & 172 & 88 \\ 160 & \text { DKVGHDFSGNDDISDVGKAY } & 179 & 88 \\ 153 & \text { DKVGYDFSGNDDIGDVAKAY } & 172 & 81 \\ 150 & \text { DKVGYDFSGNDIGDVAKAY } & 169 & 81 \\ 153 & \text { EKVGHDFSGNDDIPDVEKAY } & 172 & 81 \\ 187 & \text { EKVGYDFSGNDDISDIEEAY } & 206 & 75\end{array}$

Figure 7. Multiple alignment analysis of the deduced amino acid sequence of $U_{1}$-SCRTX-Lg1a from L. gaucho with specific fragments of phospholipases D previously reported from different species of Loxosceles spiders. Regions that show identical amino acids among all species are shaded in dark gray and those strongly conserved are shaded in light gray. Sequences alignment was performed with Clustal Omega (http://www.ebi.ac.uk/Tools/msa/clustalo/; accessed on 25 September 2018) and modified manually.

The venoms of several species are rich sources of antimicrobial molecules, and it has been suggested that the presence of these molecules is useful for organisms like spiders and scorpions to clean the biological conducts that transport venom from the gland where it is produced to the tip of the venom injector, protecting them from potential infections [1]. Based on this, the PEAKS DB searches and resulting multiple sequence alignment led us to hypothesize that, as has been previously reported in studies on AMPs derived from large proteins found in the venom of spiders and snakes $[12,62]$, $\mathrm{U}_{1}$-SCRTX-Lg1a may have originated from a limited proteolytic cleavage after $\mathrm{K}$ residues suffered from the phospholipase D LgRec1 previously isolated from the venom of L. gaucho [33], suggesting that these dermonecrotic toxins may be important factors in the immune response of Loxosceles spiders by functioning as a substrate for the generation of AMPs. 
Some physical and chemical characteristics of $\mathrm{U}_{1}$-SCRTX-Lg1a were predicted by performing a sequence analysis using the ProtParam tool available on the bioinformatics resource portal ExPASy. The net charge, grand average of hydropathicity (GRAVY), and theoretical isoelectric point (pI), among other properties, were calculated (Table 2). $\mathrm{U}_{1}$-SCRTX-Lg1a is an anionic molecule (net charge of -3 ) due to the presence in its structure of four aspartic acid residues (D), a negatively charged amino acid, and just one lysine residue $(\mathrm{K})$, which is a positively charged amino acid. Furthermore, the peptide has a $\mathrm{pI}$ of 3.77 , indicating that this is the $\mathrm{pH}$ value at which its net charge is equal to 0 . Additionally, the GRAVY score, a metric of the overall hydrophobicity/hydrophilicity of polypeptides, was in the negative range for $\mathrm{U}_{1}$-SCRTX-Lg1a $(-0.769)$, showing that this AMP could be hydrophilic in nature.

Table 2. Physicochemical parameters of U1-SCRTX-Lg1a.

\begin{tabular}{ll}
\hline Net charge & -3 \\
Theoretical isoelectric point $(\mathrm{pI})$ & 3.77 \\
Molar extinction coefficient $(\varepsilon)$ & $51,100 \mathrm{M}^{-1} \mathrm{~cm}^{-1}$ \\
Aliphatic index & 60.62 \\
GRAVY (grand average of hydropathicity) & $-0.769^{1}$ \\
Instability index & $-11.26^{2}$ \\
\hline
\end{tabular}

Physicochemical parameters were obtained using the ProtParam tool in ExPASy (http://web.expasy.org/ protparam/; accessed on 25 September 2018). ${ }^{1}$ The negative GRAVY value suggests that the peptide is hydrophilic.

2 The instability index rates this peptide as stable.

Most AMPs are cationic, which facilitates their interaction with anionic microbial membranes, leading to a variety of effects that includes membrane permeabilization, depolarization, leakage, and lysis, which ends in cell death. However, many evidences indicate that some cationic AMPs (CAMPs) can interact with intracellular anionic targets such as DNA, RNA, or cell wall components whilst others appear to have immunomodulatory properties [63]. Generally, CAMPs also have an isoelectric point close to 10 , which is very similar to detergents and is consistent with the membrane-disruptive mechanisms of action proposed for many of these peptides [64]. Taking this into account, the net negative charge of $\mathrm{U}_{1}$-SCRTX-Lg1a and its low $\mathrm{pI}$ indicate that this peptide is part of the interesting group of anionic antimicrobial peptides (AAMPs), which have been considered as an essential part of the innate immunity of vertebrates, invertebrates, and plants [63].

Because some microbial strains either possess inherent resistance to CAMPs or can develop resistance to these molecules, a rapidly growing number of AAMPs have been identified in recent years, which appear to have evolved to counter microbes with resistance to CAMPs and would thus seem well-suited for the development of novel antimicrobial agents [65]. The interaction with the membrane appears to be crucial for the antimicrobial mechanisms of AAMPs, which include toroidal pore formation and the Shai-Huang-Matsazuki model of membrane interaction along with membranolysis via tilted peptide formation and $\mathrm{pH}$-dependent amyloidogenesis [66]. However, it has also been reported that some of these AAMPs use non-membranolytic mechanisms of action that and involve the binding of metal ions through the residues of aspartic acid and glutamic acid to form cationic salt bridges with negatively charged components of microbial membranes. This action would allow the translocation of these peptides across the cell membrane into the cytoplasm, where they could act on internal cellular targets [63]. Taking into consideration that the results of the hemolytic assay suggest a non-membrane disruptive mechanism of action for $\mathrm{U}_{1}$-SCRTX-Lg1a, it would be interesting to elucidate the way in which this anionic peptide interacts with its target microorganisms in future studies.

To predict the primary and secondary structure of the peptide from its amino acid sequence, the PepDraw tool and I-TASSER server were used, respectively (Figure 8). The predicted model by I-TASSER suggests that $\mathrm{U}_{1}$-SCRTX-Lg1a tends to form an $\alpha$-helix between the ISDV residues and that the rest of the structure is a coil, which implies an absence of regular secondary structure in the largest portion of the molecule. The C-score, a measure of confidence that allows an estimation of the 
quality of the predicted structure, was -0.77 for this peptide, indicating a correct global topology for the model.

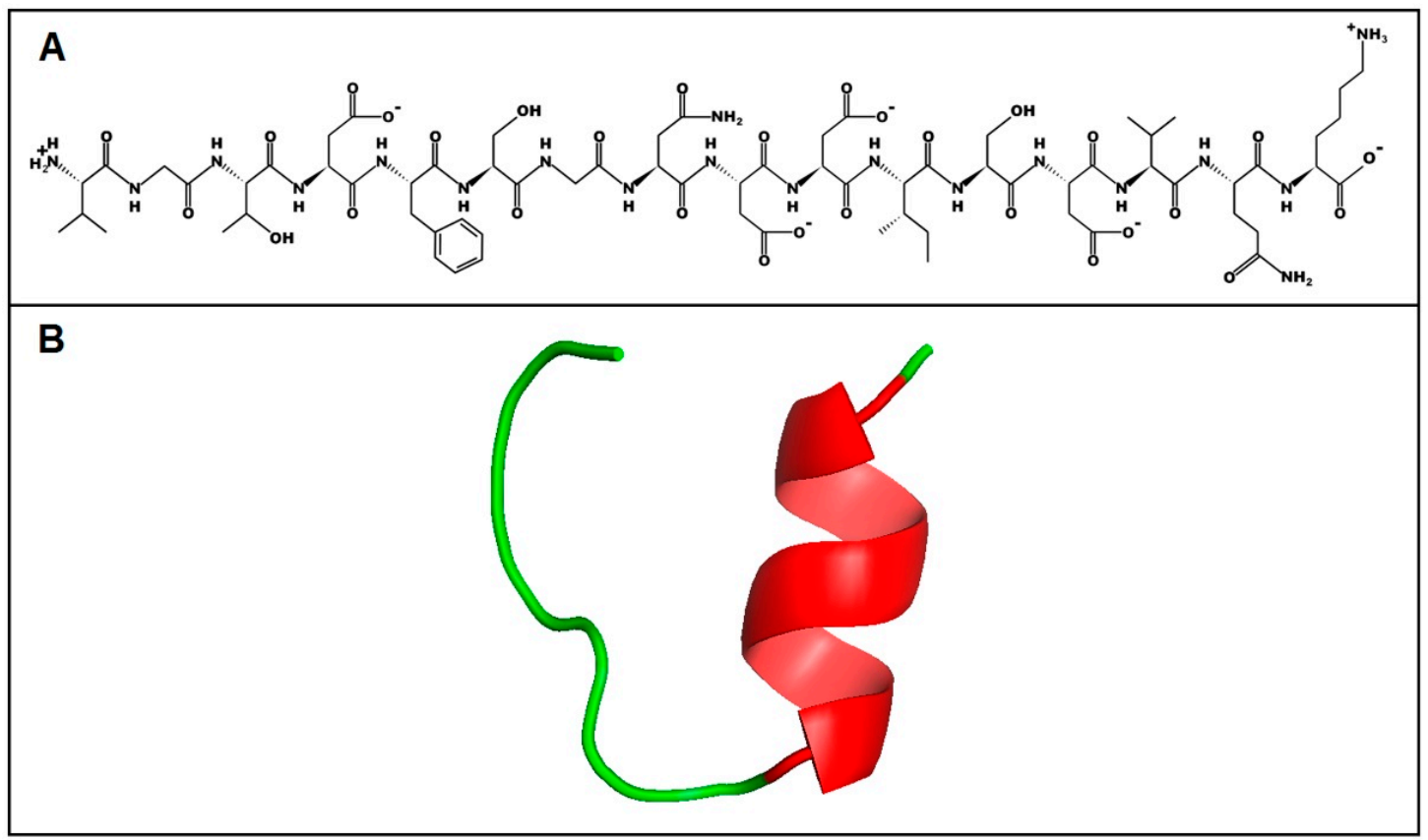

Figure 8. Structure prediction of $U_{1}$-SCRTX-Lg1a. (A) Primary structure of $U_{1}$-SCRTX-Lg1a generated by the PepDraw tool. (B) Secondary structure of $U_{1}$-SCRTX-Lg1a as predicted by the online I-TASSER server.

\section{Conclusions}

In summary, we isolated, purified, and characterized a native AAMP from the venom of the spider L. gaucho, named U U $^{-S C R T X-L g 1 a . ~ T h e ~} 1695.75$ Da peptide shows a potent and rapid antibacterial effect on different strains of Gram-negative bacteria, a lack of hemolytic activity against human erythrocytes, a lack of cytotoxicity against HeLa cells, and a remarkable similarity to specific regions of phospholipases D from different species of Loxosceles spiders. These data suggest that $\mathrm{U}_{1}$-SCRTX-Lg1a have potential for the design of novel and non-conventional therapeutic agents effective against infectious diseases caused by bacteria. Thus, the mechanism of action of $\mathrm{U}_{1}$-SCRTX-Lg1a should be determined in future studies. Finally, it is worth highlighting that this is the first peptide with antimicrobial properties described for the Loxosceles genus, whose venom has been extensively studied, indicating that this complex mixture of proteins and peptides could be a relatively untapped source of antimicrobial molecules with novel mechanisms of action.

\section{Materials and Methods}

\subsection{Microbial Strains}

Bacterial and fungal strains were obtained from the collection of microorganisms of the Special Laboratory for Applied Toxinology (LETA) of the Butantan Institute (São Paulo, Brazil). Among these strains were: E. coli SBS363, E. coli D31, P. aeruginosa ATCC 27853, P. aeruginosa PA14, E. cloacae $\beta-12, M$. luteus A270, Staphylococcus aureus ATCC 29213, Bacillus subtilis ATCC 6633, C. albicans MDM8, C. krusei IOC 4559 , and the filamentous fungus $A$. niger isolated from bread.

\subsection{Animals}

Adult specimens of L. gaucho were collected and kept alive in the bioterium of the LETA (Figure 9). The animals were collected under the Permanent License for the Collection of Zoological Material 
no. 11024-3 provided by the Brazilian Institute of Environment and Renewable Natural Resources (IBAMA) and Special Authorization for Access to Genetic Patrimony no. 001/2008.

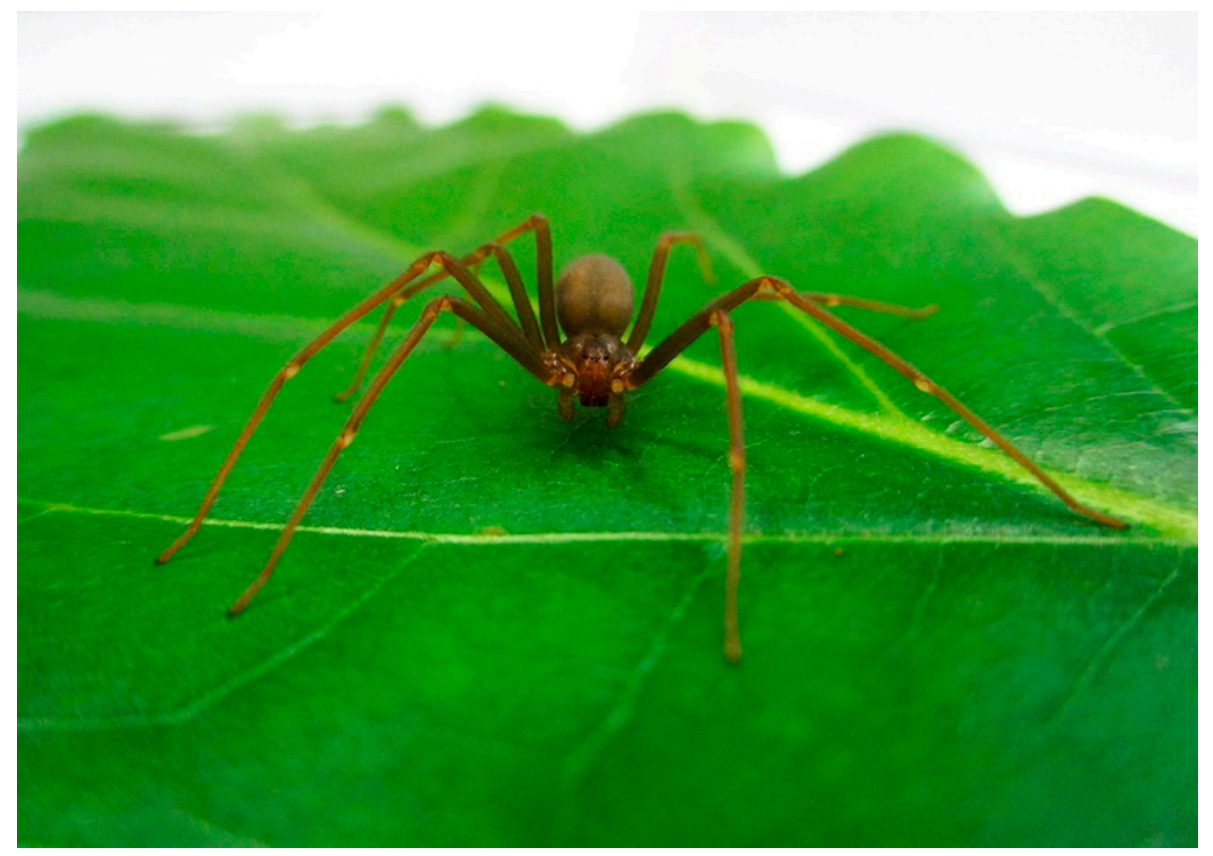

Figure 9. L. gaucho adult female (Araneae, Sicariidae).

\subsection{Venom Fractionation and $U_{1}-S C R T X-L g 1 a$ Purification}

After capture, the arachnids were kept in quarantine for seven days without food as a preparation for the extraction of venom. For this procedure, the technique performed was electrostimulation using an AVS-100 electric shock generator (AVS Projetos Especiais, São Paulo, Brazil), which consisted of applying brief $15 \mathrm{~V}$ electric shocks repeatedly to the chelicerae of the spiders until they released the venom (Figure 10). L. gaucho crude venom was collected with a micropipette, pooled in a 0.5-mL Eppendorf tube that remained on ice throughout the extraction period, and then immediately freeze-dried and stored at $-80^{\circ} \mathrm{C}$ before being resuspended in acidified water (trifluoroacetic acid (TFA) $0.05 \%$ ) for the RP-HPLC fractionation, which was carried out 18 hours later. The volume of crude venom collected was approximately $15 \mu \mathrm{L}$. The insoluble material was eliminated by centrifugation at $14,000 \times g$ for $2 \mathrm{~min}$ and the supernatant was directly subjected to RP-HPLC on a semi-preparative column Jupiter C18 (Phenomenex International, Torrance, CA, USA) equilibrated at room temperature with $0.05 \%$ TFA in ultrapure water. The purification of the sample was carried out using acetonitrile $(\mathrm{ACN}) /$ water $/ 0.05 \%$ TFA gradients of $0 \%$ to $80 \% \mathrm{ACN}$ at a flow rate of $1.5 \mathrm{~mL} / \mathrm{min}$ over $60 \mathrm{~min}$. Ultraviolet (UV) absorbance of the effluent was monitored at $225 \mathrm{~nm}$. The eluted peak fractions were manually collected and were vacuum-dried before being used in antimicrobial activity assays. The fraction with antimicrobial activity (peak 18) was further purified using a linear gradient from $26 \%$ to $46 \% \mathrm{ACN}$ at a flow rate of $1 \mathrm{~mL} / \mathrm{min}$ for $60 \mathrm{~min}$ on the same column and it was quantified based on absorbance at $205 \mathrm{~nm}$ using a NanoDrop 2000 spectrophotometer (Thermo Fisher Scientific, Waltham, MA, USA). Peptide purity of the obtained individual component with antimicrobial activity $\left(\mathrm{U}_{1}\right.$-SCRTX-Lg1a) was confirmed by mass spectrometry and amino acid sequencing. 


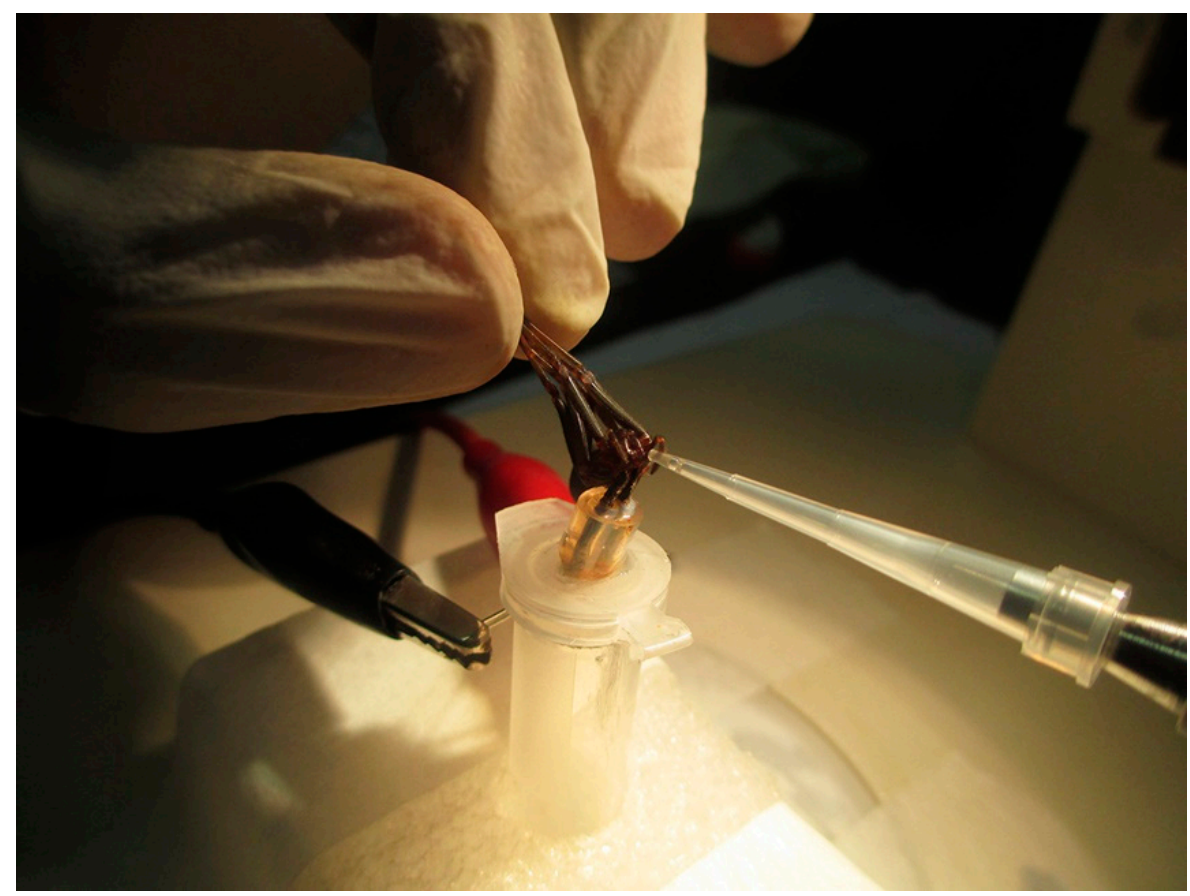

Figure 10. Venom collection of L. gaucho by electrostimulation. The spider was immobilized holding its legs back and released the venom into a $10-\mu \mathrm{L}$ pipette tip. The venom was later pooled in a $0.5-\mathrm{mL}$ Eppendorf tube.

\subsection{Antimicrobial Assays}

During the purification process, the antimicrobial effects of the fractions were evaluated by liquid growth inhibition assays against E. coli SBS363, M. luteus A270, A. niger, and C. albicans MDM8. Bacteria were cultured in poor nutrient broth $(\mathrm{PB})(1.0 \mathrm{~g}$ peptone in $100 \mathrm{~mL}$ of water containing $86 \mathrm{mM}$ $\mathrm{NaCl}$ at $\mathrm{pH} 7.4 ; 217 \mathrm{mOsm})$, and the fungus and yeasts were cultured in poor potato dextrose broth (1/2-strength PDB) (1.2 g potato dextrose in $100 \mathrm{~mL}$ of water at $\mathrm{pH} 5.0 ; 79 \mathrm{mOsm})$. Determination of antimicrobial activity was executed using a five-fold microtiter broth dilution assay in 96-well sterile plates (Shanghai Beiyi Bioequip Information Co., Ltd., Shanghai, China) at a final volume of $100 \mu \mathrm{L}$. Mid-log phase cultures were diluted to a final concentration of $5 \times 10^{4} \mathrm{CFU} / \mathrm{mL}$ for bacteria and $5 \times 10^{5} \mathrm{CFU} / \mathrm{mL}$ for the fungus and yeasts $[67,68]$. Dried fractions were dissolved in $200 \mu \mathrm{L}$ of ultrapure water and then $20 \mu \mathrm{L}$ were aliquoted into each well with $80 \mu \mathrm{L}$ of microbial dilution. The assays were carried out in duplicate. Sterile water and PB or PDB were used as controls. Tetracycline was also used as a growth inhibition control. The microtiter plates were incubated for $18 \mathrm{~h}$ at $30^{\circ} \mathrm{C}$. Growth inhibition was determined by measuring absorbance at $595 \mathrm{~nm}$.

\subsection{Concentration of $U_{1}-S C R T X-L g 1 a$}

The concentration of U1-SCRTX-Lg1a was determined through the Lambert-Beer law using the molar extinction coefficient at $205 \mathrm{~nm}$ absorption [69], obtained using the Protein Parameter Calculator tool available at the Nick Anthis website (http:/ / nickanthis.com/tools/a205.html; accessed on 25 September 2018).

\subsection{MICs of $U_{1}$-SCRTX-Lg1a}

The MICs were established using the purified fraction $\mathrm{U}_{1}$-SCRTX-Lg1a against Gram-negative bacterial strains, Gram-positive bacterial strains, a fungal strain, and a yeast strain, as described above (Section 4.1). The fraction dissolved in ultrapure water at a final concentration of $23 \mu \mathrm{M}$ was used to perform serial dilutions in 96-well sterile plates at a final volume of $100 \mu \mathrm{L}$. For that, $20 \mu \mathrm{L}$ of the fraction was applied to each well at a serial dilution of two-fold microtiter broth dilution and added 
to $80 \mu \mathrm{L}$ of the microbial dilution (modified from Ehret-Sabatier et al. [70]). Microbial growth was measured by monitoring the increase in optical density at $595 \mathrm{~nm}$ using a Victor 3TM 1420 multilabel counter (PerkinElmer, Waltham, MA, USA). The MIC was defined as the lowest concentration without visible growth after incubation at $30{ }^{\circ} \mathrm{C}$ for $18 \mathrm{~h}$. Assays were performed in duplicate.

\subsection{Determination of Hemolytic Activity}

The hemolytic activity of the $\mathrm{U}_{1}$-SCRTX-Lg1a fraction was assessed against human erythrocytes from a healthy adult donor. A $3 \%(v / v)$ suspension of washed erythrocytes in $0.15 \mathrm{M}$ phosphatebuffered saline (PBS) was incubated with $\mathrm{U}_{1}$-SCRTX-Lg1a at concentrations ranging from $0.13 \mu \mathrm{M}$ to $137 \mu \mathrm{M}$ in a U-bottom 96-well plate for $3 \mathrm{~h}$ at $37^{\circ} \mathrm{C}$ with intermittent shaking. The supernatants were first collected and transferred to a flat-bottom 96-well plate, and then hemolysis was determined by measuring the absorbance of each well at $414 \mathrm{~nm}$ in a FlexStation 3 multi-mode microplate reader (Molecular Devices, San Jose, CA, USA). Assays were conducted in triplicate. The hemolysis percentage was expressed in relation to a 100\% lysis control (erythrocytes incubated with $0.1 \%$ Triton X-100), PBS was used as a negative control, and the calculation was made according to the following equation: $\%$ hemolysis $=\left(\mathrm{A}_{\text {sample }}-\mathrm{A}_{\text {negative }}\right) /\left(\mathrm{A}_{\text {positive }}-\mathrm{A}_{\text {negative }}\right)$.

\subsection{Cytotoxicity Assay against HeLa Cells}

The toxicity of the fraction U1-SCRTX-Lg1a against HeLa cells was evaluated using the MTT colorimetric assay to measure cell viability. First, the cells were cultivated and maintained in DMEM culture medium, supplemented with $10 \%$ heat-inactivated calf serum. After that, the HeLa cells were seeded in 96-well sterile plates $\left(2 \times 10^{5}\right.$ cells/well) and cultured for $24 \mathrm{~h}$ at $37^{\circ} \mathrm{C}$ in a humidified atmosphere containing $5 \% \mathrm{CO}_{2}$. Serial dilutions of the fraction were carried out using DMEM to obtain final concentrations ranging from $0.88 \mu \mathrm{M}$ to $112.74 \mu \mathrm{M}$, which were added and allowed to react with the cells for $48 \mathrm{~h}$, followed by the addition of $20 \mu \mathrm{L}$ MTT $\left(5 \mathrm{mg} / \mathrm{mL}\right.$ in PBS) for another $4 \mathrm{~h}$ at $37^{\circ} \mathrm{C}$. Finally, $150 \mu \mathrm{L}$ of isopropanol were added to dissolve the formazan crystals. Absorbance at $550 \mathrm{~nm}$ was measured and assays were conducted in triplicate. Cell survival was calculated according to the following equation: \% survival $=\left(\mathrm{A}_{\text {treated cells }} / \mathrm{A}_{\text {untreated cells }}\right) \times 100$.

\subsection{SDS-PAGE Analysis}

Samples of $L$. gaucho crude venom $(5 \mu \mathrm{g})$ and $\mathrm{U}_{1}$-SCRTX-Lg1a $(2.5 \mu \mathrm{g})$ were analyzed by $12 \%$ tris-glycine SDS-PAGE under non-reducing conditions [71], using a Spectra Multicolor Broad Range Protein Ladder (Thermo Fisher Scientific, Waltham, MA, USA) to estimate the molecular mass. Before the electrophoresis, the samples were solubilized in sample buffer. The total running time was $3 \mathrm{~h}$ at $120 \mathrm{~V}$. After electrophoresis, the gel was stained with silver nitrate [72].

\subsection{Mass Spectrometry Analysis and $U_{1}-S C R T X-L g 1 a$ Identification}

The fraction $\mathrm{U}_{1}$-SCRTX-Lg1a was analyzed in positive ion mode on an LTQ Orbitrap Velos mass spectrometer (Thermo Fisher Scientific, Bremen, Germany) coupled to an Easy-nLC II (Thermo Fisher Scientific, Bremen, Germany), according to Abreu et al. [12] with some modifications. The mass spectrometer was programmed for a full scan, recorded between $\mathrm{m} / z 300$ and 2000 with a resolution of 60,000 (at $m / z$ 400). The 10 most abundant peaks were fragmented using collision-induced dissociation (CID) and analyzed in an ion trap. The isolation window for precursor ions was set to $2 \mathrm{~m} / \mathrm{z}$, the minimum count of ions to trigger events $\left(\mathrm{MS}^{2}\right)$ was 10,000, and the dynamic exclusion time was set to $90 \mathrm{~s}$. Normalized collision energy was set to $35 \%$. In order to identify the $\mathrm{U}_{1}$-SCRTX-Lg1a fraction, mass spectrometry (MS) raw data were processed and searched in the PEAKS Studio software (v8; Bioinformatics Solutions, Waterloo, ON, Canada) [73]. To determine its amino acid sequence, we performed de novo sequencing from MS/MS data with the following parameters: a precursor mass tolerance of $10 \mathrm{ppm}$ and a fragment ion mass tolerance of 0.5 . De novo peptides, whose ALC scores 
$\geq 80 \%$ were searched against the UniProt-SwissProt database using the PEAKS DB tool. The peptide false discovery rate (FDR) was predictable by the decoy fusion method and was selected at a maximum of $1 \%$.

\subsection{1. $U_{1}$-SCRTX-Lg1a Analysis with Bioinformatics Tools}

The resulting amino acid sequence of $U_{1}$-SCRTX-Lg1a was submitted to searches for regions of local similarity against proteins from arthropods registered on the public database provided at the National Center for Biotechnology Information (NCBI) website using BLAST (https:/ /blast.ncbi.nlm. nih.gov / Blast.cgi; accessed on 25 September 2018). The physicochemical parameters of the sequence were calculated using the ProtParam tool available on the bioinformatics resource portal ExPASy of the Swiss Institute of Bioinformatics (SIB) website (http:/ / web.expasy.org/protparam/; accessed on 25 September 2018). Finally, the potential primary structure of $U_{1}$-SCRTX-Lg1a was generated using the PepDraw tool provided by the Wimley laboratory (Tulane University, New Orleans, LA, USA) (http:/ / www.tulane.edu/ \{\}biochem/WW/PepDraw/; accessed on 25 September 2018), and the online I-TASSER server available on the Yang Zhang laboratory website (http:/ / zhanglab.ccmb.med. umich.edu/I-TASSER/; accessed on 25 September 2018) was used to obtain a three-dimensional (3D) image of its secondary structure.

Author Contributions: Conceptualization, P.J.S.-R. and P.I.S.J.; Data curation, P.J.S.-R.; Formal analysis, P.J.S.-R.; Funding acquisition, P.I.S.J.; Investigation, P.J.S.-R.; Methodology, P.I.S.J.; Project administration, P.I.S.J.; Resources, P.I.S.J.; Supervision, P.I.S.J.; Validation, P.J.S.-R. and P.I.S.J.; Writing—original draft, P.J.S.-R.; Writing—review and editing, P.J.S.-R. and P.I.S.J.

Funding: This research was funded by the Research Support Foundation of the State of São Paulo (FAPESP/CeTICS), (Grant No. 2013/07467-1) and the Brazilian National Council for Scientific and Technological Development (CNPq) (Grant No. 472744/2012-7).

Acknowledgments: We would like to thank Andrea Díaz Roa for her diligent help with part of the experimental work, as well as the two reviewers and the assistant editor, Cindy Sun, for their valuable comments that have considerably improved the manuscript.

Conflicts of Interest: The authors declare no conflict of interest.

\section{References}

1. Garcia, F.; Villegas, E.; Espino-Solis, G.P.; Rodriguez, A.; Paniagua-Solis, J.F.; Sandoval-Lopez, G.; Possani, L.D.; Corzo, G. Antimicrobial peptides from arachnid venoms and their microbicidal activity in the presence of commercial antibiotics. J. Antibiot. 2013, 66, 3-10. [CrossRef] [PubMed]

2. Harrison, P.L.; Abdel-Rahman, M.A.; Miller, K.; Strong, P.N. Antimicrobial peptides from scorpion venoms. Toxicon 2014, 88, 115-137. [CrossRef]

3. Peters, B.M.; Shirtliff, M.E.; Jabra-Rizk, M.A. Antimicrobial peptides: Primeval molecules or future drugs? PLoS Pathog. 2010, 6, e1001067. [CrossRef] [PubMed]

4. Teixeira, V.; Feio, M.J.; Bastos, M. Role of lipids in the interaction of antimicrobial peptides with membranes. Prog. Lipid Res. 2012, 51, 149-177. [CrossRef]

5. Mechkarska, M.; Attoub, S.; Sulaiman, S.; Pantic, J.; Lukic, M.L.; Conlon, J.M. Anti-cancer, immunoregulatory, and antimicrobial activities of the frog skin host-defense peptides pseudhymenochirin- $1 \mathrm{~Pb}$ and pseudhymenochirin-2Pa. Regul. Pept. 2014, 194-195, 69-76. [CrossRef]

6. Narayana, J.L.; Chen, J.Y. Antimicrobial peptides: Possible anti-infective agents. Peptides 2015, 72, 88-94. [CrossRef] [PubMed]

7. Steinstraesser, L.; Kraneburg, U.; Jacobsen, F.; Al-Benna, S. Host defense peptides and their antimicrobialimmunomodulatory duality. Immunobiology 2011, 216, 322-333. [CrossRef]

8. Corzo, G.; Villegas, E.; Gómez-Lagunas, F.; Possani, L.D.; Belokoneva, O.S.; Nakajima, T. Oxyopinins, large amphipathic peptides isolated from the venom of the wolf spider Oxyopes kitabensis with cytolytic properties and positive insecticidal cooperativity with spider neurotoxins. J. Biol. Chem. 2002, 277, 23627-23637. [CrossRef] 
9. Kozlov, S.A.; Vassilevski, A.A.; Feofanov, A.V.; Surovoy, A.Y.; Karpunin, D.V.; Grishin, E.V. Latarcins, antimicrobial and cytolytic peptides from the venom of the spider Lachesana tarabaevi (Zodariidae) that exemplify biomolecular diversity. J. Biol. Chem. 2006, 281, 20983-20992. [CrossRef]

10. Yan, L.; Adams, M.E. Lycotoxins, antimicrobial peptides from venom of the wolf spider Lycosa carolinensis. J. Biol. Chem. 1998, 273, 2059-2066. [CrossRef]

11. Nicholson, G.M. Spider peptides. In Handbook of Biologically Active Peptides, 2nd ed.; Kastin, A.J., Ed.; Academic Press: Los Angeles, CA, USA, 2013; pp. 461-472. ISBN 978-0-12-385095-9.

12. Abreu, T.F.; Sumitomo, B.N.; Nishiyama, M.Y., Jr.; Oliveira, U.C.; Souza, G.H.; Kitano, E.S.; Zelanis, A.; Serrano, S.M.; Junqueira-de-Azevedo, I.; Silva, P.I., Jr.; et al. Peptidomics of Acanthoscurria gomesiana spider venom reveals new toxins with potential antimicrobial activity. J. Proteomics 2017, 151, 232-242. [CrossRef] [PubMed]

13. Ayroza, G.; Ferreira, I.L.; Sayegh, R.S.; Tashima, A.K.; Silva, P.I., Jr. Juruin: An antifungal peptide from the venom of the Amazonian Pink Toe spider, Avicularia juruensis, which contains the inhibitory cystine knot motif. Front Microbiol. 2012, 3, 324. [CrossRef] [PubMed]

14. Lazarev, V.N.; Shkarupeta, M.M.; Polina, N.F.; Kostrjukova, E.S.; Vassilevski, A.A.; Kozlov, S.A.; Grishin, E.V.; Govorun, V.M. Antimicrobial peptide from spider venom inhibits Chlamydia trachomatis infection at an early stage. Arch. Microbiol. 2013, 195, 173-179. [CrossRef] [PubMed]

15. Lei, Q.; Yu, H.; Peng, X.; Yan, S.; Wang, J.; Yan, Y.; Wang, X. Isolation and preliminary characterization of proteinaceous toxins with insecticidal and antibacterial activities from black widow spider (L. tredecimguttatus) eggs. Toxins 2015, 7, 886-889. [CrossRef] [PubMed]

16. Santos, D.M.; Verly, R.M.; Piló-Veloso, D.; de Maria, M.; de Carvalho, M.A.; Cisalpino, P.S.; Soares, B.M.; Diniz, C.G.; Farias, L.M.; Moreira, D.F.; et al. LyeTx I, a potent antimicrobial peptide from the venom of the spider Lycosa erythrognatha. Amino Acids 2010, 39, 135-144. [CrossRef] [PubMed]

17. Tan, H.; Ding, X.; Meng, S.; Liu, C.; Wang, H.; Xia, L.; Liu, Z.; Liang, S. Antimicrobial potential of lycosin-I, a cationic and amphiphilic peptide from the venom of the spider Lycosa singorensis. Curr. Mol. Med. 2013, 13, 900-910. [CrossRef] [PubMed]

18. Wang, Y.; Wang, L.; Yang, H.; Xiao, H.; Farooq, A.; Liu, Z.; Hu, M.; Shi, X. The spider venom peptide Lycosin-II has potent antimicrobial activity against clinically isolated bacteria. Toxins 2016, 8, 119. [CrossRef]

19. De Oliveira, K.C.; Gonçalves de Andrade, R.M.; Piazza, R.M.; Ferreira, J.M., Jr.; van den Berg, C.W.; Tambourgi, D.V. Variations in Loxosceles spider venom composition and toxicity contribute to the severity of envenomation. Toxicon 2005, 45, 421-429. [CrossRef]

20. Chaim, O.M.; Trevisan-Silva, D.; Chaves-Moreira, D.; Wille, A.C.; Ferrer, V.P.; Matsubara, F.H.; Mangili, O.C.; da Silveira, R.B.; Gremski, L.H.; Gremski, W.; et al. Brown spider (Loxosceles genus) venom toxins: Tools for biological purposes. Toxins 2011, 3, 309-344. [CrossRef]

21. Gremski, L.H.; Trevisan-Silva, D.; Ferrer, V.P.; Matsubara, F.H.; Meissner, G.O.; Wille, A.C.; Vuitika, L.; Dias-Lopes, C.; Ullah, A.; de Moraes, F.R.; et al. Recent advances in the understanding of brown spider venoms: From the biology of spiders to the molecular mechanisms of toxins. Toxicon 2014, 83, 91-120. [CrossRef]

22. Manríquez, J.J.; Silva, S. Cutaneous and visceral loxoscelism: A systematic review. Rev. Chilena Infectol. 2009, 26, 420-432. [CrossRef] [PubMed]

23. Buch, D.R.; Souza, F.N.; Meissner, G.O.; Morgon, A.M.; Gremski, L.H.; Ferrer, V.P.; Trevisan-Silva, D.; Matsubara, F.H.; Bóia-Ferreira, M.; Sade, Y.B.; et al. Brown spider (Loxosceles genus) venom toxins: Evaluation of biological conservation by immune cross-reactivity. Toxicon 2015, 108, 154-166. [CrossRef] [PubMed]

24. Matsubara, F.H.; Gremski, L.H.; Meissner, G.O.; Soares, E.C.; Gremski, W.; Senff-Ribeiro, A.; Chaim, O.M.; Veiga, S.S. A novel ICK peptide from the Loxosceles intermedia (brown spider) venom gland: Cloning, heterologous expression and immunological cross-reactivity approaches. Toxicon 2013, 71, 147-158. [CrossRef] [PubMed]

25. Senff-Ribeiro, A.; da Silva, P.H.; Chaim, O.M.; Gremski, L.H.; Paludo, K.S.; da Silveira, R.B.; Gremski, W.; Mangili, O.C.; Veiga, S.S. Biotechnological applications of brown spider (Loxosceles genus) venom toxins. Biotechnol. Adv. 2008, 26, 210-218. [CrossRef] [PubMed] 
26. Appel, M.H.; da Silveira, R.B.; Chaim, O.M.; Paludo, K.S.; Trevisan-Silva, D.; Chaves-Moreira, D.; da Silva, P.H.; Mangili, O.C.; Senff-Ribeiro, A.; Gremski, W.; et al. Identification, cloning and functional characterization of a novel dermonecrotic toxin (phospholipase D) from brown spider (Loxosceles intermedia) venom. Biochim. Biophys. Acta 2008, 1780, 167-178. [CrossRef] [PubMed]

27. Binford, G.J.; Cordes, M.H.; Wells, M.A. Sphingomyelinase D from venoms of Loxosceles spiders: Evolutionary insights from cDNA sequences and gene structure. Toxicon 2005, 45, 547-560. [CrossRef] [PubMed]

28. Da Silveira, R.B.; Pigozzo, R.B.; Chaim, O.M.; Appel, M.H.; Dreyfuss, J.L.; Toma, L.; Mangili, O.C.; Gremski, W.; Dietrich, C.P.; Nader, H.B.; et al. Molecular cloning and functional characterization of two isoforms of dermonecrotic toxin from Loxosceles intermedia (Brown spider) venom gland. Biochimie 2006, 88, 1241-1253. [CrossRef]

29. Da Silveira, R.B.; Pigozzo, R.B.; Chaim, O.M.; Appel, M.H.; Trevisan-Silva, D.; Dreyfuss, J.L.; Toma, L.; Dietrich, C.P.; Nader, H.B.; Veiga, S.S.; et al. Two novel dermonecrotic toxins LiRecDT4 and LiRecDT5 from Brown spider (Loxosceles intermedia) venom: From cloning to functional characterization. Biochimie 2007, 89, 289-300. [CrossRef]

30. Dantas, A.E.; Carmo, A.O.; Horta, C.C.; Leal, H.G.; Oliveira-Mendes, B.B.; Martins, A.P.; Chávez-Olórtegui, C.; Kalapothakis, E. Description of Loxtox protein family and identification of a new group of Phospholipases D from Loxosceles similis venom gland. Toxicon 2016, 120, 97-106. [CrossRef]

31. De Giuseppe, P.O.; Ullah, A.; Trevisan-Silva, D.; Gremski, L.H.; Wille, A.C.; Chaves-Moreira, D.; Senff-Ribeiro, A.; Chaim, O.M.; Murakami, M.T.; Veiga, S.S.; et al. Structure of a novel class II phospholipase D: Catalytic cleft is modified by a disulphide bridge. Biochem. Biophys. Res. Commun. 2011, 409, 622-627. [CrossRef]

32. Kalapothakis, E.; Chatzaki, M.; Gonçalves-Dornelas, H.; de Castro, C.S.; Silvestre, F.G.; Laborne, F.V.; de Moura, J.F.; Veiga, S.S.; Chávez-Olórtegui, C.; Granier, C.; et al. The loxtox protein family in Loxosceles intermedia (Mello-Leitão) venom. Toxicon 2007, 50, 938-946. [CrossRef] [PubMed]

33. Magalhães, G.S.; Caporrino, M.C.; Della-Casa, M.S.; Kimura, L.F.; Prezotto-Neto, J.P.; Fukuda, D.A.; Portes-Junior, J.A.; Neves-Ferreira, A.G.; Santoro, M.L.; Barbaro, K.C. Cloning, expression and characterization of a phospholipase D from Loxosceles gaucho venom gland. Biochimie 2013, 95, 1773-1783. [CrossRef] [PubMed]

34. Wille, A.C.; Chaves-Moreira, D.; Trevisan-Silva, D.; Magnoni, M.G.; Boia-Ferreira, M.; Gremski, L.H.; Gremski, W.; Chaim, O.M.; Senff-Ribeiro, A.; Veiga, S.S. Modulation of membrane phospholipids, the cytosolic calcium influx and cell proliferation following treatment of B16-F10 cells with recombinant phospholipase-D from Loxosceles intermedia (brown spider) venom. Toxicon 2013, 67, 17-30. [CrossRef] [PubMed]

35. Zobel-Thropp, P.A.; Kerins, A.E.; Binford, G.J. Sphingomyelinase D in sicariid spider venom is a potent insecticidal toxin. Toxicon 2012, 60, 265-271. [CrossRef] [PubMed]

36. Da Silveira, R.B.; dos Santos Filho, J.F.; Mangili, O.C.; Veiga, S.S.; Gremski, W.; Nader, H.B.; von Dietrich, C.P. Identification of proteases in the extract of venom glands from brown spiders. Toxicon 2002, 40, 815-822. [CrossRef]

37. Da Silveira, R.B.; Wille, A.C.; Chaim, O.M.; Appel, M.H.; Silva, D.T.; Franco, C.R.; Toma, L.; Mangili, O.C.; Gremski, W.; Dietrich, C.P.; et al. Identification, cloning, expression and functional characterization of an astacin-like metalloprotease toxin from Loxosceles intermedia (brown spider) venom. Biochem. J. 2007, 406, 355-363. [CrossRef] [PubMed]

38. Feitosa, L.; Gremski, W.; Veiga, S.S.; Elias, M.C.; Graner, E.; Mangili, O.C.; Brentani, R.R. Detection and characterization of metalloproteinases with gelatinolytic, fibronectinolytic and fibrinogenolytic activities in brown spider (Loxosceles intermedia) venom. Toxicon 1998, 36, 1039-1051. [CrossRef]

39. Morgon, A.M.; Belisario-Ferrari, M.R.; Trevisan-Silva, D.; Meissner, G.O.; Vuitika, L.; Marin, B.; Tashima, A.K.; Gremski, L.H.; Gremski, W.; Senff-Ribeiro, A.; et al. Expression and immunological cross-reactivity of LALP3, a novel astacin-like metalloprotease from brown spider (Loxosceles intermedia) venom. Biochimie 2016, 128-129, 8-19. [CrossRef]

40. Trevisan-Silva, D.; Gremski, L.H.; Chaim, O.M.; da Silveira, R.B.; Meissner, G.O.; Mangili, O.C.; Barbaro, K.C.; Gremski, W.; Veiga, S.S.; Senff-Ribeiro, A. Astacin-like metalloproteases are a gene family of toxins present in the venom of different species of the brown spider (genus Loxosceles). Biochimie 2010, 92, 21-32. [CrossRef] 
41. Trevisan-Silva, D.; Bednaski, A.V.; Gremski, L.H.; Chaim, O.M.; Veiga, S.S.; Senff-Ribeiro, A. Differential metalloprotease content and activity of three Loxosceles spider venoms revealed using two-dimensional electrophoresis approaches. Toxicon 2013, 76, 11-22. [CrossRef]

42. Barbaro, K.C.; Knysak, I.; Martins, R.; Hogan, C.; Winkel, K. Enzymatic characterization, antigenic cross-reactivity and neutralization of dermonecrotic activity of five Loxosceles spider venoms of medical importance in the Americas. Toxicon 2005, 45, 489-499. [CrossRef] [PubMed]

43. Da Silveira, R.B.; Chaim, O.M.; Mangili, O.C.; Gremski, W.; Dietrich, C.P.; Nader, H.B.; Veiga, S.S. Hyaluronidases in Loxosceles intermedia (Brown spider) venom are endo-beta-N-acetyl-d-hexosaminidases hydrolases. Toxicon 2007, 49, 758-768. [CrossRef]

44. Dos Santos, L.D.; Dias, N.B.; Roberto, J.; Pinto, A.S.; Palma, M.S. Brown recluse spider venom: Proteomic analysis and proposal of a putative mechanism of action. Protein Pept. Lett. 2009, 16, 933-943. [CrossRef] [PubMed]

45. Ferrer, V.P.; de Mari, T.L.; Gremski, L.H.; Trevisan-Silva, D.; da Silveira, R.B.; Gremski, W.; Chaim, O.M.; Senff-Ribeiro, A.; Nader, H.B.; Veiga, S.S. A novel hyaluronidase from brown spider (Loxosceles intermedia) venom (Dietrich's Hyaluronidase): From cloning to functional characterization. PLoS Negl. Trop. Dis. 2013, 7, e2206. [CrossRef] [PubMed]

46. Young, A.R.; Pincus, S.J. Comparison of enzymatic activity from three species of necrotising arachnids in Australia: Loxosceles rufescens, Badumna insignis and Lampona cylindrata. Toxicon 2001, 39, 391-400. [CrossRef]

47. Fernandes-Pedrosa, M.F.; Junqueira-de-Azevedo, I.L.; Gonçalves-de-Andrade, R.M.; Kobashi, L.S.; Almeida, D.D.; Ho, P.L.; Tambourgi, D.V. Transcriptome analysis of Loxosceles laeta (Araneae, Sicariidae) spider venomous gland using expressed sequence tags. BMC Genomics 2008, 9, 279. [CrossRef] [PubMed]

48. Gremski, L.H.; da Silveira, R.B.; Chaim, O.M.; Probst, C.M.; Ferrer, V.P.; Nowatzki, J.; Weinschutz, H.C.; Madeira, H.M.; Gremski, W.; Nader, H.B.; et al. A novel expression profile of the Loxosceles intermedia spider venomous gland revealed by transcriptome analysis. Mol. Biosyst. 2010, 6, 2403-2416. [CrossRef] [PubMed]

49. Machado, L.F.; Laugesen, S.; Botelho, E.D.; Ricart, C.A.; Fontes, W.; Barbaro, K.C.; Roepstorff, P.; Sousa, M.V. Proteome analysis of brown spider venom: Identification of loxnecrogin isoforms in Loxosceles gaucho venom. Proteomics 2005, 5, 2167-2176. [CrossRef]

50. Veiga, S.S.; da Silveira, R.B.; Dreyfus, J.L.; Haoach, J.; Pereira, A.M.; Mangili, O.C.; Gremski, W. Identification of high molecular weight serine-proteases in Loxosceles intermedia (brown spider) venom. Toxicon 2000, 38, 825-839. [CrossRef]

51. Sade, Y.B.; Bóia-Ferreira, M.; Gremski, L.H.; da Silveira, R.B.; Gremski, W.; Senff-Ribeiro, A.; Chaim, O.M.; Veiga, S.S. Molecular cloning, heterologous expression and functional characterization of a novel translationally-controlled tumor protein (TCTP) family member from Loxosceles intermedia (brown spider) venom. Int. J. Biochem. Cell Biol. 2012, 44, 170-177. [CrossRef]

52. De Castro, C.S.; Silvestre, F.G.; Araújo, S.C.; Yazbeck, G.M.; Mangili, O.C.; Cruz, I.; Chávez-Olórtegui, C.; Kalapothakis, E. Identification and molecular cloning of insecticidal toxins from the venom of the brown spider Loxosceles intermedia. Toxicon 2004, 44, 273-280. [CrossRef] [PubMed]

53. Meissner, G.O.; de Resende Lara, P.T.; Scott, L.P.; Braz, A.S.; Chaves-Moreira, D.; Matsubara, F.H.; Soares, E.M.; Trevisan-Silva, D.; Gremski, L.H.; Veiga, S.S.; et al. Molecular cloning and in silico characterization of knottin peptide, U2-SCRTX-Lit2, from brown spider (Loxosceles intermedia) venom glands. J. Mol. Model. 2016, 22, 196. [CrossRef] [PubMed]

54. King, G.F.; Gentz, M.C.; Escoubas, P.; Nicholson, G.M. A rational nomenclature for naming peptide toxins from spiders and other venomous animals. Toxicon 2008, 52, 264-276. [CrossRef] [PubMed]

55. De Oliveira Domingos, M.; Neves, I.V.; Vigerelli, H.; Pimenta, D.C.; de Carvalho Lins Fernandes Távora, B.; Lemos, T.J.; Franzolin, M.R.; Marques, V.D.; Barbaro, K.C. The potential of Loxosceles gaucho spider venom to regulate Pseudomonas aeruginosa mechanisms of virulence. Toxicon 2018, 152, 78-83. [CrossRef] [PubMed]

56. Chaparro, E.; da Silva, P.I., Jr. Lacrain: The first antimicrobial peptide from the body extract of the Brazilian centipede Scolopendra viridicornis. Int. J. Antimicrob. Agents 2016, 48, 277-285. [CrossRef] [PubMed]

57. Silva, P.I., Jr.; Daffre, S.; Bulet, P. Isolation and characterization of Gomesin, an 18-residue cysteine-rich defense peptide from the spider Acanthoscurria gomesiana hemocytes with sequence similarities to horseshoe crab antimicrobial peptides of the tachyplesin family. J. Biol. Chem. 2000, 275, 33464-33470. [CrossRef] [PubMed] 
58. Gruenheid, S.; Le Moual, H. Resistance to antimicrobial peptides in Gram-negative bacteria. FEMS Microbiol. Lett. 2012, 330, 81-89. [CrossRef]

59. Sardar, A.H.; Das, S.; Agnihorti, S.; Kumar, M.; Ghosh, A.K.; Abhishek, K.; Kumar, A.; Purkait, B.; Ansari, M.Y.; Das, P. Spinigerin induces apoptotic like cell death in a caspase independent manner in Leishmania donovani. Exp. Parasitol. 2013, 135, 715-725. [CrossRef]

60. Oddo, A.; Hansen, P.R. Hemolytic activity of antimicrobial peptides. Methods Mol. Biol. 2017, 1548, 427-435. [CrossRef]

61. Betts, M.J.; Russell, R.B. Amino acid properties and consequences of substitutions. In Bioinformatics for Geneticists; Barnes, M.R., Gray, I.C., Eds.; John Wiley \& Sons: Hoboken, NJ, USA, 2003; pp. 289-316, ISBN 9780470867303.

62. Santamaría, C.; Larios, S.; Quirós, S.; Pizarro-Cerda, J.; Gorvel, J.P.; Lomonte, B.; Moreno, E. Bactericidal and antiendotoxic properties of short cationic peptides derived from a snake venom Lys49 phospholipase A2. Antimicrob. Agents Chemother. 2005, 49, 1340-1345. [CrossRef]

63. Harris, F.; Dennison, S.R.; Phoenix, D.A. Anionic antimicrobial peptides from eukaryotic organisms. Curr. Protein Pept. Sci. 2009, 10, 585-606. [CrossRef] [PubMed]

64. Torrent, M.; Andreu, D.; Nogués, V.M.; Boix, E. Connecting peptide physicochemical and antimicrobial properties by a rational prediction model. PLoS ONE 2011, 6, e16968. [CrossRef] [PubMed]

65. Dennison, S.R.; Howe, J.; Morton, L.H.; Brandenburg, K.; Harris, F.; Phoenix, D.A. Interactions of an anionic antimicrobial peptide with Staphylococcus aureus membranes. Biochem. Biophys. Res. Commun. 2006, 347, 1006-1010. [CrossRef] [PubMed]

66. Dennison, S.R.; Harris, F.; Mura, M.; Phoenix, D.A. An atlas of anionic antimicrobial peptides from amphibians. Curr. Protein Pept. Sci. 2018, 19, 823-838. [CrossRef] [PubMed]

67. Bulet, P. Strategies for the discovery, isolation, and characterization of natural bioactive peptides from the immune system of invertebrates. Methods Mol. Biol. 2008, 494, 9-29. [CrossRef] [PubMed]

68. Hetru, C.; Bulet, P. Strategies for the isolation and characterization of antimicrobial peptides of invertebrates. Methods Mol. Biol. 1997, 78, 35-49. [CrossRef]

69. Anthis, N.J.; Clore, G.M. Sequence-specific determination of protein and peptide concentrations by absorbance at $205 \mathrm{~nm}$. Protein Sci. 2013, 22, 851-858. [CrossRef]

70. Ehret-Sabatier, L.; Loew, D.; Goyffon, M.; Fehlbaum, P.; Hoffmann, J.A.; van Dorsselaer, A.; Bulet, P. Characterization of novel cysteine-rich antimicrobial peptides from scorpion blood. J. Biol. Chem. 1996, 271, 29537-29544. [CrossRef]

71. Laemmli, U.K. Cleavage of structural proteins during the assembly of the head of bacteriophage T4. Nature 1970, 227, 680-685. [CrossRef]

72. Morrissey, J.H. Silver stain for proteins in polyacrylamide gels: A modified procedure with enhanced uniform sensitivity. Anal. Biochem. 1981, 117, 307-310. [CrossRef]

73. Ma, B.; Zhang, K.; Hendrie, C.; Liang, C.; Li, M.; Doherty-Kirby, A.; Lajoie, G. PEAKS: Powerful software for peptide de novo sequencing by tandem mass spectrometry. Rapid Commun. Mass Spectrom. 2003, 17, 2337-2342. [CrossRef] [PubMed]

(c) 2018 by the authors. Licensee MDPI, Basel, Switzerland. This article is an open access article distributed under the terms and conditions of the Creative Commons Attribution (CC BY) license (http://creativecommons.org/licenses/by/4.0/). 